J. Asiat. Soc. Bangladesh, Sci. 45(1): 1-14, June, 2019

\title{
BREEDING BIRDS AT THE CHITTAGONG UNIVERSITY CAMPUS OF CHITTAGONG IN BANGLADESH
}

\author{
M. FARID AHSAN* AND M. MANIRUL ISLAM \\ Department of Zoology, University of Chittagong, Chittagong, Bangladesh
}

\begin{abstract}
A study on the breeding birds in the Chittagong University Campus (CUC) of Chittagong, Bangladesh was carried out, through direct field observations during January to June 2011. Fifty-five species of birds belonging to 27 families under 11 orders were observed to breed in the CUC. A total of 819 breeding pairs of birds were recorded, of which $25(45.45 \%)$ species were passerines and 30 (54.55\%) nonpasserines. Among the breeding birds, the Asian pied starling (Gracupica contra) was the highest in number/frequency, comprised 128 (15.63\% of the total) pairs and yellow footed green pigeon (Treron phoenicopterus) was the lowest, 1 ( $0.12 \%$ of the total) pair. Among the 27 families, Family Corvidae comprised the highest number of breeding species (7, 12.73\%); Family Sturnidae and Passeridae had 4 species each (7.27\%); while 4 families included 3 (5.46\%), 7 families had 2 (3.64\%) and 14 families had only 1 $(1.82 \%)$ breeding species each. The maximum nest building was recorded in April 276 $(33.70 \%)$ and minimum in January $31(3.78 \%)$. The highest number of nests were built in plants $370(45.18 \%)$ and among the rest $279(34.06 \%)$ in buildings, $116(14.16 \%)$ in hill slopes, $46(5.62 \%)$ in lampposts and $8(0.98 \%)$ in the ground. The birds were recorded to use 32 species of plants under 20 families, of which $21(65.63 \%)$ were indigenous and $11(34.37 \%)$ were exotic species for breeding purpose only. Mango (Mangifera indica) supported the highest number of bird species for nesting about 59 $(15.94 \%)$ while the second highest was coconut (Cocos nucifera) $52(14.05 \%)$, and plant species like Bhadi (Garuga pinnata) and Pitraj (Aphanamixis polystachya) was the lowest species of only $1(0.27 \%)$. Among the 370 nests, $295(79.73 \%)$ were recorded in the indigenous plants and the rest $75(20.27 \%)$ were in the exotic species. Habitat degradation and destruction, pollution in and around CUC, planting exotic species, human settlements, collection of litters and firewood, and occasional fires are hampering breeding activities of birds in the CUC. Necessary steps are to be taken to overcome the problems and protect their breeding and feeding habitats, and further study is needed to know detail of their breeding behaviour.
\end{abstract}

Key words: Breeding birds, Nesting plants, Nesting substrates, Chittagong University Campus

\section{Introduction}

Breeding is the natural process of reproduction in the animal kingdom that is, producing of offspring for the perpetuation of the race or species. Birds breed through laying eggs by the females after mating with males and through incubating. Birds' show breeding

*Author for correspondence: <faridahsan55@yahoo.com>. 
activities in different means such as, calling or singing, counter-calling, territoriality, agile movements, exhibiting breeding plumage, etc. to the opposite sex and/or rivals. Breeding of birds in an area reflects the quality of that habitat. The Chittagong University Campus (CUC) is a unique place for many species of bird to live and breed. More than 150 species of birds have been recorded from the CUC (M. F. Ahsan pers. obs.), although Asmat et al. (1985) reported 79 species, Ahsan and Khanom (2005) recorded 92 species from the campus and Kamruzzaman et al. (2007) added 34 species more to the list. Recently Kabir et al. (2017) reported 215 species from the campus excluding 39 species which were mentioned by early authors, although these were not seen between 2007 and 2014, but the total number of breeding species has not yet been recognized. That is why, one of the author (MFA) became interested to know the number of bird species breed in the CUC area. Therefore, an attempt was taken to study the breeding birds, breeding habitats and breeding season of the birds in the CUC.

\section{Materials and Methods}

The Chittagong University Campus is situated at Fatehpur, a village under Hathazari

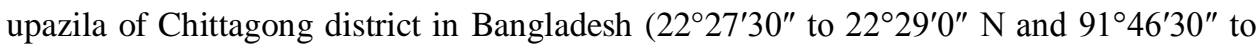
$\left.91^{\circ} 47^{\prime} 45^{\prime \prime} \mathrm{E}\right)$. It is about $23 \mathrm{~km}$ north of the Chittagong city area and $3 \mathrm{~km}$ south-west of Hathazari upazila headquarter and the campus is quite big, consists of about 709.78 ha $(1,753.88$ acres) of land decked with about $72 \%$ hills, lakes, ponds and plain land with stunningly green tall trees. The CUC is one of the floristically rich areas in Chittagong. It is situated in such an ideal place where hills, valleys and plain land are interwoven which is ideal representative place for plant exploration in Chittagong district. A total of 665 plant species (550 species dicotyledons and 115 monocotyledons) under 404 genera and 126 families are found in the CUC (Alam and Pasha 1999).

The breeding birds of CUC were studied during January to June, 2011. The total CUC area was divided into four sites (S-A, S-B, S-C and S-D) for the convenience of the study (Fig. 1). S-A included the University Railway Station to Shaheed Minar through right side of the Katapahar road and from No. 1 to No. 2 gates including the surrounding areas; S-B covered the area from Shaheed Minar to Institute of Marine Sciences and Fisheries, and from Shaheed Minar to Central Field and its adjacent areas including Shaheed Abdur Rab Hall; S-C comprised of the area from Biological Faculty to Botanic Garden and its adjacent areas; and S-D encompassed Botanic Garden to Institute of Forestry and Environmental Sciences, and the University Railway Station to Shaheed Minar through the left side of Katapahar road and its adjacent areas. 


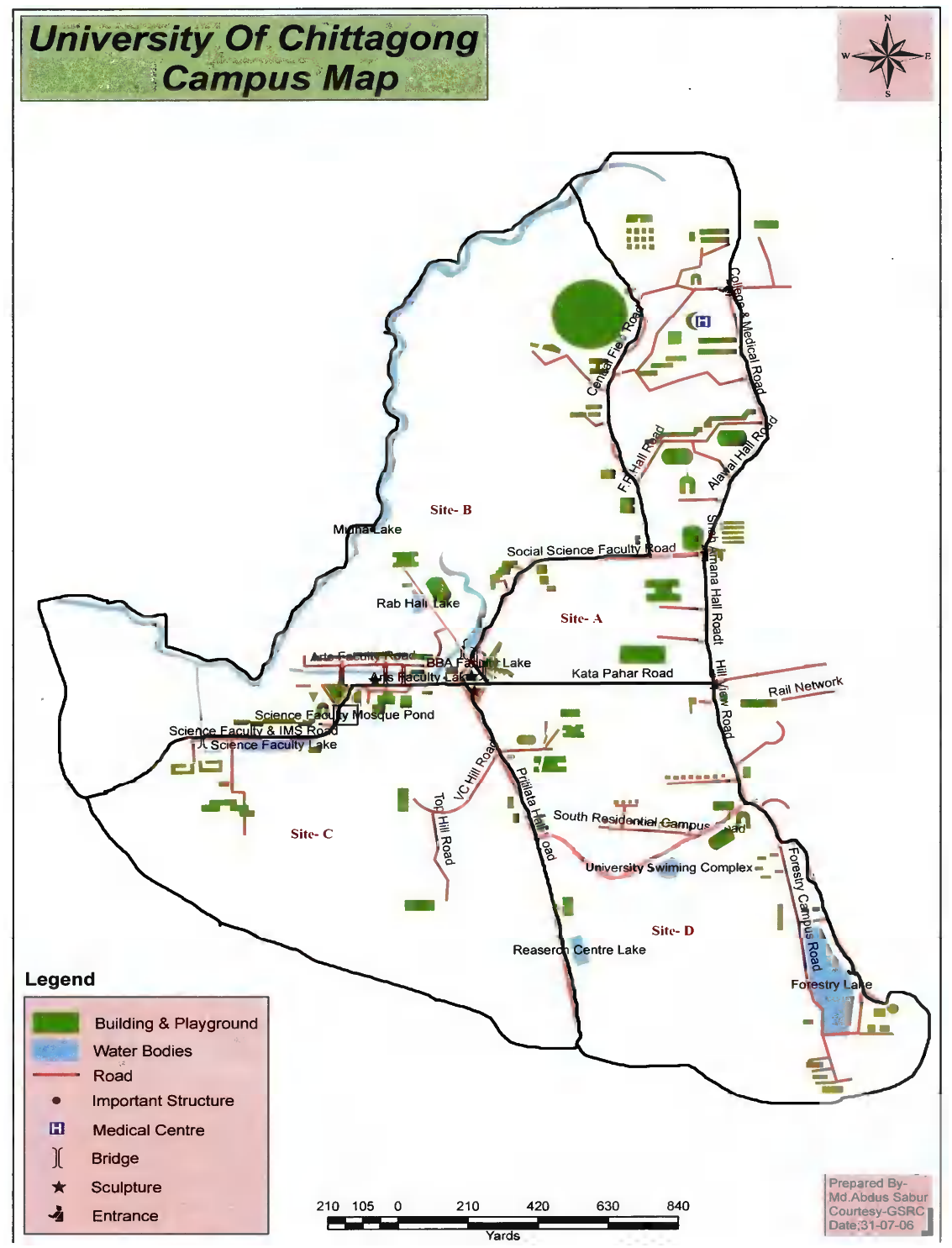

Fig. 1. Map of the CUC area with marked study sites.

Fortnight field observations were made for collecting data during the study period. Singing and calling sounds, breeding plumage, carrying nest materials and/or food for nestlings, seeing the eggs and/or nestlings, birds sitting on/in nests were considered for confirming the breeding birds in the CUC (Table 1). Besides enlisting breeding species of 
birds, nest, nesting site, nesting tree and nest height from the ground were also recorded (Table 2). The birds were observed either by naked eyes and/or with the help of a pair of binoculars (Bushnell $10 \times 40$ ). A field guide book (e.g., Grimmett et al. 2006) was used (when necessary) for the identification of species and a digital camera (Sony Cyber shot 10.1 Mega pixels, Model no. DSC-H20) was also used for documenting photographs.

\section{Results}

Fifty-five species of birds belonging to 27 families under 11 orders were observed to breed in the CUC during January to June, 2011 (Table 1). A total of 819 breeding pair of birds (Table 3) was recorded of which 25 (45.45\%) species were passerines and 30 (54.55\%) non-passerines (Table 1). Among the breeding pairs, 289 (35.3\% of the total) belonged to 20 species in S-A; 143 (17.45\% of the total) comprised of 23 species in S-B; 161 (19.65\% of the total) included 29 species in S-C and 226 (27.6\% of the total) contained 21 species in S-D (Table 2). Among the breeding species of birds, the Asian pied starling (Gracupica contra) was the highest in frequency, which comprised of 128 (15.63\% of the total) pairs and yellow-footed green pigeon (Treron phoenicopterus) was the lowest, 1 (0.12\% of the total) pair (Table 2).

Table 1. Breeding bird species in the Chittagong University Campus.

\begin{tabular}{lllll}
\hline $\begin{array}{l}\text { Sl. } \\
\text { No. }\end{array}$ & Family & $\begin{array}{l}\text { Scientific } \\
\text { name }\end{array}$ & $\begin{array}{l}\text { Common } \\
\text { name }\end{array}$ & $\begin{array}{l}\text { Vernacular } \\
\text { name }\end{array}$ \\
\hline & Non-passerine & & & \\
1 & Phasianidae & Gallus gallus & Red jungle fowl & Lal Bonmurgi \\
2 & Picidae & $\begin{array}{l}\text { Dendrocopos macei } \\
\text { Dinopium benghalense }\end{array}$ & $\begin{array}{l}\text { Fulvous breasted woodpecker } \\
\text { Lesser golden back woodpecker }\end{array}$ & $\begin{array}{l}\text { Batabi Kathkurali } \\
\text { Bangla Kaththokra }\end{array}$ \\
3 & & Megalaima lineata & Lineated barbet & Dagi Boshonta \\
4 & Capitonidae & Coracias benghalensis & Indian roller & Neelkanta \\
5 & Coraciidae & Common kingfisher & Pati Machranga \\
6 & Alcedinidae & Alcedo atthis & White-throated kingfisher & Dholagola Machranga \\
7 & Dalcelonidae & Halcyon smyrnensis & Pied kingfisher & Pakra Machranga \\
8 & Cerylidae & Ceryle rudis & Chestnut-headed bee-eater & Khoiramatha Shuichora \\
9 & Meropidae & Merops leschenaultia & Green bee-eater & Banaspati \\
10 & & Merops orientalis & Blue-tailed bee-eater & Neel-lej Shuichora \\
11 & & Merops philippinus & Common hawk-cuckoo & Pati Chokhgelo \\
12 & Cuculidae & Hierococcyx varius & Esian koel & Kokil \\
13 & & Eudynamys scolopaceus & Asial & Shobuj Thot Malkoa \\
14 & & Phaenicophacus tristis & Green-billed malkoha & Kukka \\
\hline 15 & Centropodidae & Centropus bengalensis & Lesser coucal &
\end{tabular}




\begin{tabular}{|c|c|c|c|c|}
\hline 16 & & Centropus sinensis & Greater coucal & Kana-Kua \\
\hline 17 & Psittacidae & Psittacula alexandri & Red-breasted parakeet & Modna Tia \\
\hline 18 & & Psittacula krameri & Rose-ringed parakeet & Shobuj Tia \\
\hline 19 & Apodidae & Cypsiurus balasiensis & Asian palm swift & Nakkati \\
\hline 20 & & Apus nipalensis & Little /House swift & Ghor Batashi \\
\hline 21 & Tytonidae & Tyto alba & Barn owl & Laksmi Pecha \\
\hline 22 & Strigidae & Athene brama & Spotted owlet & Kutare Pencha \\
\hline 23 & Columbidae & Columba livia & Rock pigeon & Jalali Kobutor \\
\hline 24 & & Streptopelia chinensis & Spotted dove & Tila Ghughu \\
\hline 25 & & Treron phoenicopterus & Yellow-footed green pigeon & Holdepa Horial \\
\hline 26 & Rallidae & Amaurornis phoenicurus & White-breasted waterhen & Dahuk \\
\hline 27 & Jacanidae & Metopidius indicus & Bronze-winged jacana & Dol Pipi \\
\hline 28 & Charadriidae & Vanellus indicus & Red-wattled lapwing & Lal Lotika Hot-ti-ti \\
\hline 29 & Ardeidae & Bubulcus ibis & Cattle egret & Go-Bok \\
\hline 30 & & Ardeola grayii & Indian pond heron & Kani Bok \\
\hline & Passerine & & & \\
\hline 31 & Laniidae & Lanius schach & Long-tailed shrike & Lenja Latora \\
\hline 32 & Corvidae & Dendrocitta vagabunda & Rufous treepie & Hari Chacha \\
\hline 33 & & Corvus splendens & House crow & Pati Kak \\
\hline 34 & & Corvus macrorhynchos & Large-billed crow & Danr Kak \\
\hline 35 & & Artamus fuscus & Ashy woodswallow & Metey Bonababil \\
\hline 36 & & Oriolus xanthornus & Black hooded oriole & Halde Pakhi \\
\hline 37 & & Dicrurus macrocercus & Black drongo & Kala Fingey \\
\hline 38 & & Aegithina tiphia & Common iora & Fatik Jal \\
\hline 39 & Muscicapidae & Copsychus saularis & Oriental magpie robin & Doel \\
\hline 40 & Sturnidae & Gracupica contra & Asian pied starling & Gobrey Shalik \\
\hline 41 & & Sturnus malabarica & Chestnut-tailed starling & Kath Shalik \\
\hline 42 & & Acridotheres tristis & Common myna & Bhat Shalik \\
\hline 43 & & Acridotheres fuscus & Jungle myna & Jhuti Shalik \\
\hline 44 & Paridae & Parus major & Great tit & Tit Pankhi \\
\hline 45 & Pycnonotidae & Pycnonotus cafer & Red-vented bulbul & Bulbul \\
\hline 46 & & Pycnonotus jocosus & Red-whiskered bulbul & Sipahi Bulbul \\
\hline 47 & Silvidae & Orthotomus sutorius & Common tailorbird & Pati Tuntuni \\
\hline 48 & & Garrulax ruficollis & Rufous necked laughing-thrush & Lalghar Penga \\
\hline 49 & Nectariniidae & Dicaeum cruentatum & Scarlet backed flowerpecker & Lalpith Fuljhuri \\
\hline 50 & & Leptocoma zeylonica & Purple-rumped sunbird & Begunikomor Moutushi \\
\hline 51 & & Cinnyris asiaticus & Purple sunbird & Beguni Moutushi \\
\hline 52 & Passeridae & Passer domesticus & House sparrow & Pati Chorui \\
\hline 53 & & Ploceus philippinus & Baya weaver & Deshi Babui \\
\hline 54 & & Lonchura malacca & Black-headed munia & Kalamatha Munia \\
\hline 55 & & Lonchura punctulata & Scally-breasted munia & Tila Munia \\
\hline
\end{tabular}




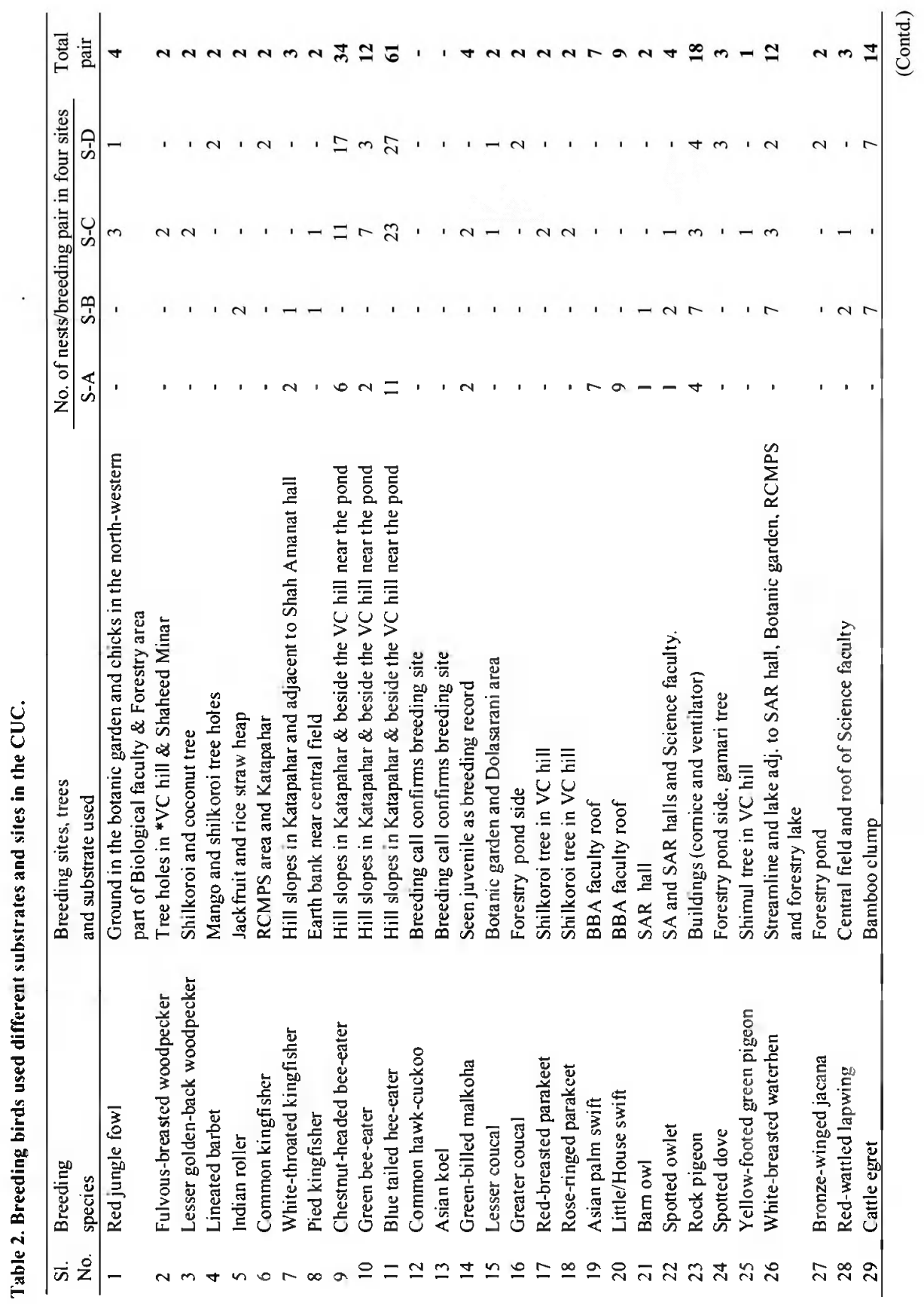


Breeding birds at the Chittagong University Campus

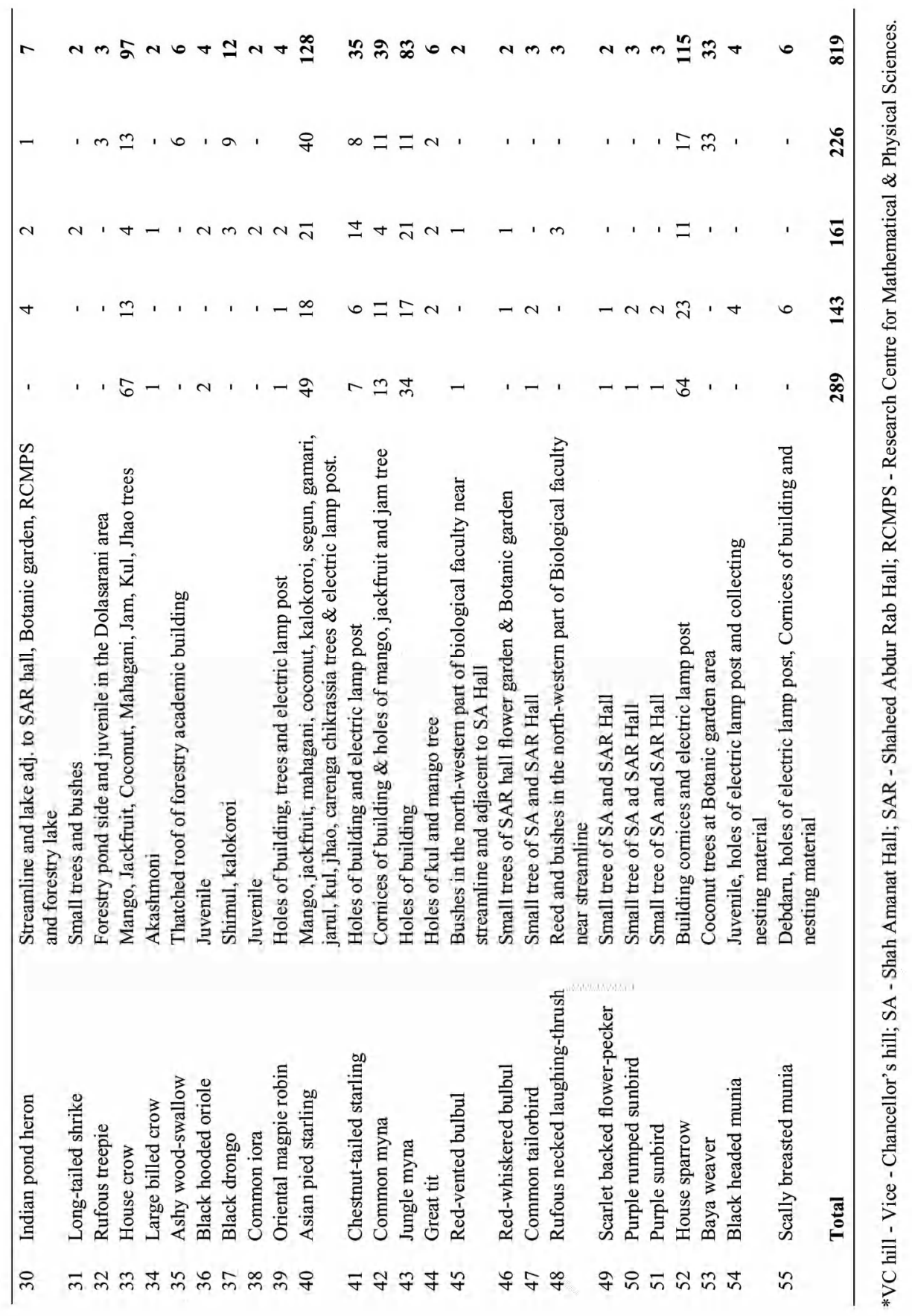


Table 3. Month-wise recorded breeding pairs at 4-site in the CUC.

\begin{tabular}{lccccc}
\hline Month & Site-A & Site-B & Site-C & Site-D & Sub-total \\
\hline January & 16 & 7 & 4 & 4 & 31 \\
February & 23 & 13 & 9 & 14 & 59 \\
March & 57 & 28 & 39 & 47 & 171 \\
April & 91 & 41 & 65 & 79 & 276 \\
May & 53 & 29 & 40 & 47 & 169 \\
June & 27 & 21 & 29 & 36 & 113 \\
Total & $\mathbf{2 6 7}$ & $\mathbf{1 3 9}$ & $\mathbf{1 8 6}$ & $\mathbf{2 2 7}$ & $\mathbf{8 1 9}$ \\
\hline
\end{tabular}

Breeding habitat analysis: The breeding birds in the CUC used nesting in trees, building hollows or holes and cornices, ground holes, ground, tree holes, electric lamp posts and roof of thatched houses. The present data (Table 4) reveal that the highest number of nests $370(45.18 \%)$ were found in plants, the second highest was $279(34.06 \%)$ nests in buildings, and the lowest number of nests $8(0.98 \%)$ were located on the ground.

Table 4. Recorded substrates of the breeding pairs in the CUC.

\begin{tabular}{lcc}
\hline Breeding substrates & Total no. of pairs & \% of total pairs \\
\hline Plant species & 370 & 45.18 \\
Buildings and walls & 279 & 34.06 \\
Hill slopes & 116 & 14.16 \\
Lamp post & 46 & 5.62 \\
Ground and earth bank & 8 & 0.98 \\
Total & $\mathbf{8 1 9}$ & $\mathbf{1 0 0 . 0 0}$ \\
\hline
\end{tabular}

The recorded nesting habitats of breeding substrates of all 55 breeding species in four sites of the CUC were located (Table 2). Seven species of birds (rock pigeon, house crow, Asian pied starling, chestnut-tailed starling, common myna, jungle myna and house sparrow) nested in all four sites in the CUC, of which the highest number of nests (128) was built by Asian pied starling and the lowest number of nests (35) was constructed by common myna (Table 2). Three sites were used for nesting by eight species of birds, two sites by 17 species and single site by 21 species. Two species of parasitic birds (common hawk cuckoo and Asian koel) were found to lay eggs in the nests of other birds.

Similar groups of species selected same site(s) for nesting, for instance, bee-eaters (chestnut-headed, green and blue-tailed) nested in sites A, C and D; Asian palm swift and house swift chosen site A. Site $\mathrm{C}$ was chosen by the maximum number of species (34) of 
birds followed by site B preferred by 25 species, and both sites A and D were selected for nesting by 24 species of birds. Among the single site nesting birds eight species selected site $\mathrm{C}$, seven species preferred site $\mathrm{D}$, four species chosen site $\mathrm{B}$ and two species opted for site A. The maximum number of nests (289) were spotted in site A followed by 226 nests in site D, 161 nests in site C and 143 nests in site B.

House sparrow (Passer domesticus), jungle myna (Acridotheres fuscus), rock pigeon (Columba livia), etc. used the building hollows and cornices for constructing nests (Table 2). Bee-eaters (Merops spp.) and kingfishers (common kingfisher [Alcedo atthis], whitethroated kingfisher [Halcyon smyrnensis] and pied kingfisher [Ceryle rudis]) used the self-made holes in the hill slopes, while Asian pied starling (Gracupica contra), house crow (Corvus splendens) and others used various trees like shil koroi (Albizia lebbek), coconut (Coccos nucifera), jackfruit (Artocarpus heterophyllus), mango (Mangifera indica), shimul (Salmalia malabaricum), jarul (Lagerstroemia speciosa), gamari (Gmelina arborea) and other large trees (Table 2). The chestnut-tailed starling (Sturnus malabarica) utilized mainly the electric lamp posts and building holes; while ashy wood swallow (Artamus fuscus), Asian palm swift (Cypsiurus balasiensis) and little/house swift (Apus nipalensis) used the thatched roofs and cornices of the buildings (Table 2). The nesting heights were from ground to several meters high and it varied even within the species.

During the study period, 370 nests of 55 species of birds were spotted in 22 plant species in the CUC, of which 295 nests were built in indigenous plant species (Table 5). The maximum number of nests (59) were found in Aam trees (Mangifera indica) followed by 52 on Dab/Narikel palm (Coccus nucifera), 52 on Kanthal trees (Artocarpus heterophyllus), and the lowest number of nest (1) was found in Bhadi (Garuga pinnata) and Pitraj (Aphanamixis polystachya) trees (Table 5). On the other hand, 75 nests were located in 11 exotic plant species, of which the highest number (23) of nests came across in Jhau (Casuarina littorea) followed by Jarul (15) trees (Lagerstroemia speciosa), and the lowest number (2) of nests were seen in each Akashmoni (Acacia moniliformis) and Christmas (Araucaria columnaris) trees (Table 5).

Breeding season: The breeding season of birds at the CUC spreads over January to June. The highest number of breeding pairs, 276 (33.70\%) were recorded in April and minimum, 31 (3.78\%) in January (Table 3). The breeding season of the recorded bird species varied between and even within species. It depends on the physical, physiological, environmental conditions and also food resources. 


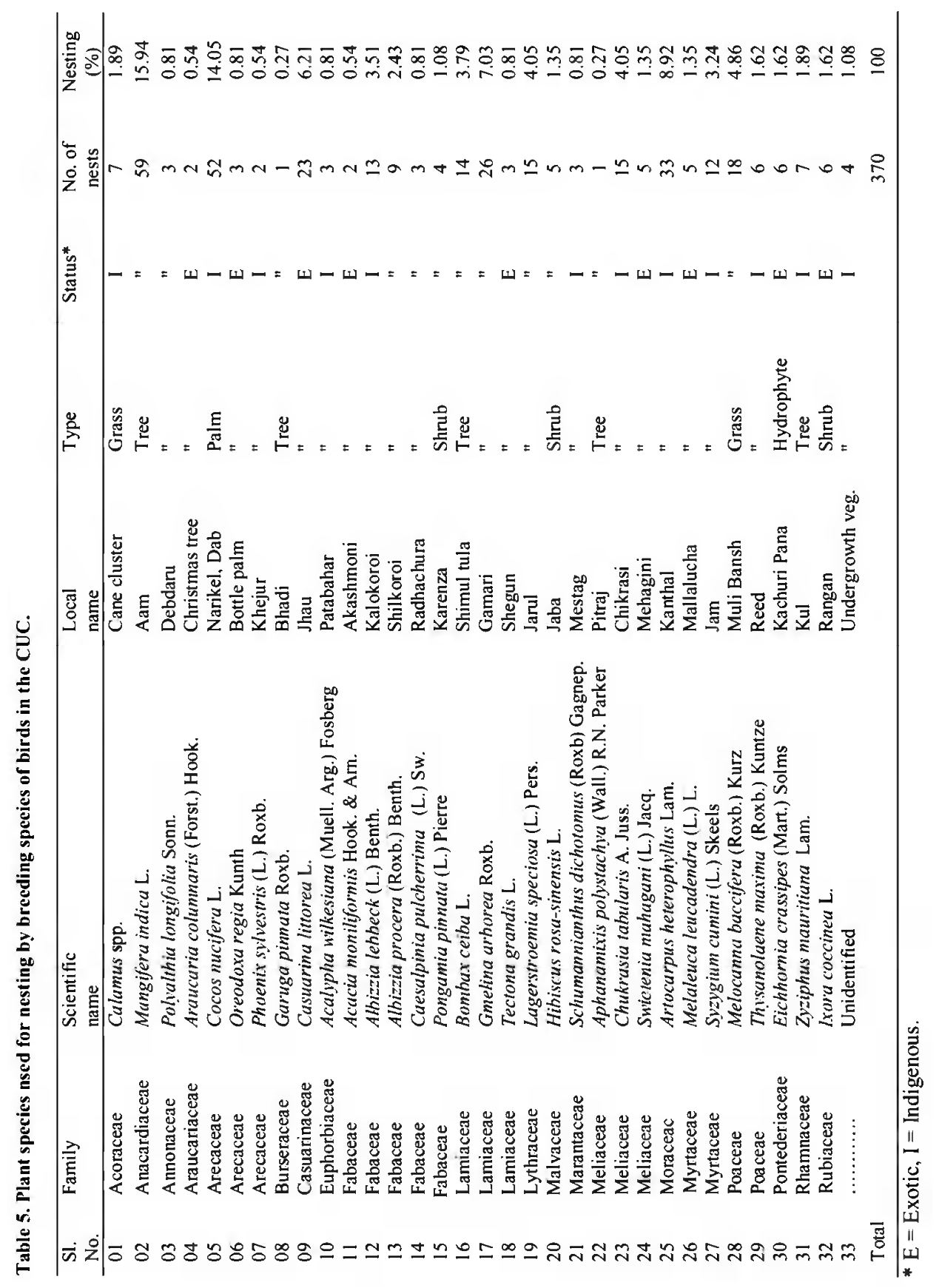




\section{Discussion}

Out of 650 species of birds in Bangladesh (Siddiqui et al. 2008), 188 species breed and a further 59 are likely to breed (Harvey 1990) in the country. The present study confirms that 55 species of birds breed in the CUC, which is nearly $30 \%$ of the country's breeding species, and the number is likely to be increased, so, that will be the areas of future studies.

Among the breeding birds, house crow (Corvus splendens) and Asian pied starling (Gacupica contra) play a vital role in keeping healthy environment through scavenging. Huge amount of waste materials are being produced everyday at the CUC area, which are being reduced through consumption mainly by these two species among the birds. Some other bird species also play important role in pollinating, pest controlling, seed dispersing, etc. and thus birds are helping in maintaining ecological balance.

The main threats of these breeding birds at CUC are the unplanned settlements and agricultural practices, and recently introduce fish culture in the derelict ponds through cleaning and re-excavating. These directly affect breeding and feeding habitats of the birds. Cultivation of agricultural crops and burning herbs, bushes and shrubs in the hills, collecting firewood, litter-fall, etc. have negative effects on the natural activities of birds. Another threat for breeding birds is the shortage of suitable breeding habitats like indigenous tree species and presence of huge exotic species. Planted exotic species of trees play harmful effects on the environment and virtually birds avoid building nests in exotic species. Only 75 pairs (9.16\% of the total recorded pairs) of bird out of 819 pairs observed to build nests in exotic species during the study period. Among the 55 species Asian pied starling (Gracupica contra), common myna (Acridotheres tristis), house crow (Corvus splendens), large-billed crow (Corvus macrorhynchos), white-breasted waterhen (Amaurornis phoenicurus) and bronze-winged jacana (Metopidius indicus) were noticed to nest in the exotic plants. The breeding pairs used exotic plant species for nesting most probably due to the shortage of suitable indigenous nesting trees nearby because in the CUC area huge number of exotic plant species were planted by the authority and these birds are trying to adapt themselves with the new environment. But, planting native fruiting trees is essential through eradicating exotic tree species for birds for keeping healthy environment and balanced ecosystems for humans also in the CUC.

The breeding season and clutch size of breeding species of birds in the CUC have been compared (Table 6) with the records of Ali and Ripley (1983) including two-year-round breeder species (Asian palm swift and rock pigeon). The available data (Table 6) reveal that the breeding season of birds in the CUC is mostly same with that of the Ali and Ripley (1983). A few additions to the report of Ali and Ripley (1983) are: in CUC barn owl breeds during April - July, red-wattled lapwing during March - July and the breeding call of common hawk cuckoo recorded during March - June. Breeding season of the birds 


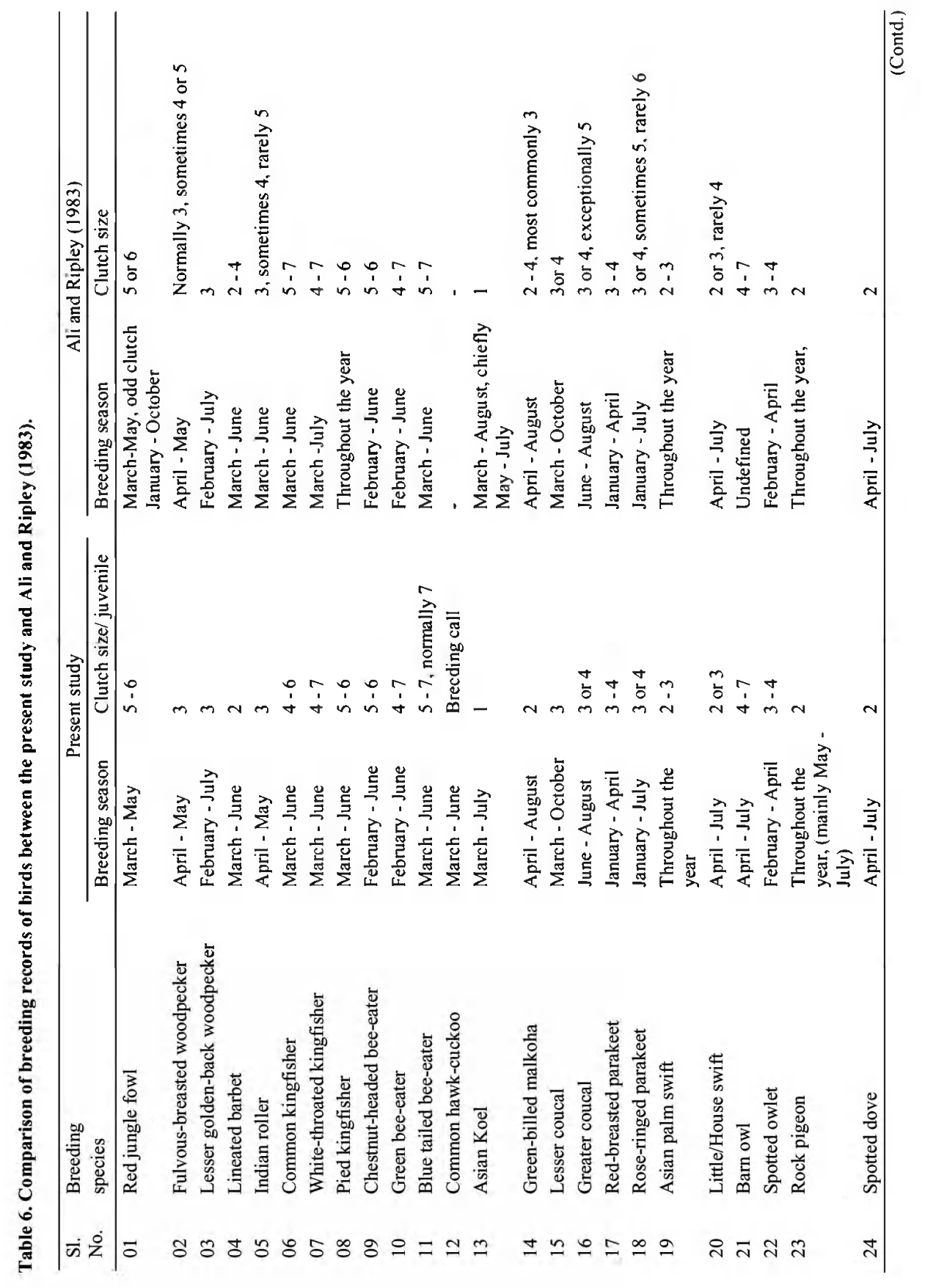




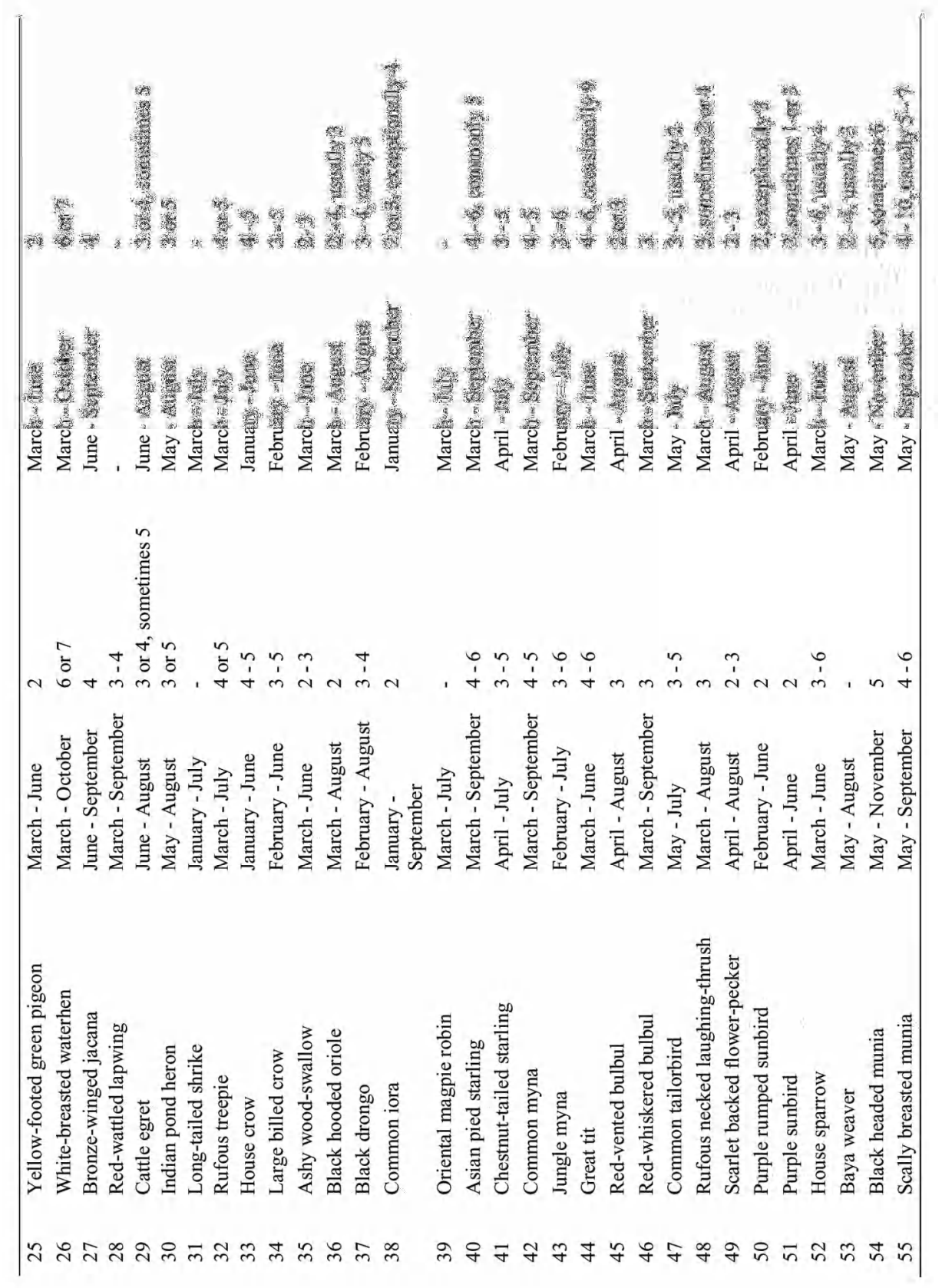


in the CUC starts in January but the majority (24 species) starts in March and the maximum (16 species) complete by June.

The clutch size of birds varied from 2 to 7 in the CUC, which are mostly similar with Ali and Ripley (1983) with slightly different in a few cases (Table 6). Two eggs were laid by lineated barbet, green-billed malkoha, rock pigeon, spotted dove, yellow-footed pigeon, black-hooded oriole, common iora, purple-rumped sun bird and purple sun bird; while seven or up to seven eggs laid by white-throated kingfisher, green bee-eater, blue-tailed bee-eater, barn owl and white-breasted waterhen (Table 6).

\section{Conclusion}

The population of some bird species is decreasing but the diversity is increasing in the Chittagong University Campus (CUC) day by day (M. F. Ahsan pers. obs. since 1982). Habitat degradation and destruction, pollution in and around CUC, planting exotic species, human settlements, collection of litters and firewood, cutting undergrowth and bushes for sealing litters in the sacs, and occasional fire hampering breeding activities of

birds in the CUC. For conserving bird species in the CUC, it is necessary to take steps to overcome the mentioned problems.

\section{References}

Ahsan, M.F. and N. Khanom. 2005. Birds of the Chittagong University Campus, Chittagong. The Chittagong Univ. J. Sci. 29(1): 77-88.

Alam, M.N. and M.K. Pasha. 1999. A floristic account of Chittagong University campus. The Chittagong Univ. J. Sci. 23(1): 81-99.

Ali, S. and S.D Ripley. 1983. Handbook of the Birds of India and Pakistan together with Those of Bangladesh, Nepal, Bhutan and Sri Lanka, Compact Edition. Oxford University Press, Delhi, Oxford, New York. xiii $+737+113$ color plates.

Asmat, G.S.M., B. Ahmed and M.M. Rahman. 1985. Avifauna of the Chittagong University Campus. Bangladesh J. Zool. 13(2): 23-29.

Grimmett, R., C Inskipp and P. Inskipp. 2006. Pocket Guide to the Birds of the Indian Subcontinent, $1^{\text {st }}$ edition. Oxford University Press, New Delhi. 384 pp.

Harvey, W.G. 1990. Birds in Bangladesh. University Press Limited, Dhaka. 188 pp.

Kabir, M.T., M F Ahsan, M.M Rahman and M.M. Islam. 2017 A checklist of the avian fauna of Chittagong University Campus, Bangladesh. J. Treatened Taxa. 9(6): 10325-10333.

Kamruzzaman, M., M.U.H. Khatun, Q. Banu and G.S.M. Asmat 2007. Additions to the birds of the Chittagong University Campus. J. Taxon. Biodiv. Res. 1(1): 59-60.

Siddiqui, K.U, M.A. Islam, S.M.H Kabir, M Ahmad, A.T.A Ahmed, A.K.A Rahman, E.U Haque, Z.U Ahmed, Z.N.T Begum, M.A Hassan, M. Khondker and M.M. Rahman (eds.) 2008. Encyclopedia of Flora and Fauna of Bangladesh. Vol. 26. Birds. Asiatic Society of Bangladesh, Dhaka. 662 pp.

(Revised copy received 01.04.2019) 